\title{
Nodular Pulmonary Amyloidosis Mimicking Breast Carcinoma Metastasis
}

\author{
Meme Karsinom Metastazını Taklit Eden Nodüler Pulmoner Amiloidoz
}

Ezgi Çimen Çelik', Serkan Yazgan', Soner Gürsoy' ${ }^{1}$ Ahmet Ucvet' ${ }^{1}$ Zekiye Aydoğdu²

\section{Abstract}

Amyloidosis is a disease that is characterized by an extracellular accumulation of fibril proteins called amyloid in tissues, and organ dysfunction. There are various types of amyloidosis, with nodular pulmonary amyloidosis usually considered a subtype of $A L$ amyloidosis. Surgical excision is usually curative and the prognosis is excellent. This case is presented to emphasize the rare occurrence of pulmonary amyloidosis and the need to keep malignancies in mind in differential diagnosis.

Key words: Amiloidosis, breast cancer, metastasis.

\section{Özet}

Amiloidoz, dokularda amiloid adı verilen fibril yapısındaki proteinlerin ekstrasellüler birikimi ve organlarda işlev bozukluğu ile seyreden hastalıktır. Çeşitli tipleri olup, nodüler pulmoner amiloidoz, genellikle AL amiloidozun bir subtipi olarak görülür. Cerrahi eksizyon genellikle küratiftir ve prognoz mükemmeldir. Bu olgu, pulmoner amiloidozun nadiren görülmesi, ayırıcı tanıda malignitelerin akılda tutulması gerekliliğini vurgulamak amacıyla sunulmuştur.

Anahtar Sözcükler: Amiloidoz, meme karsinomu, metastaz.
'Department of Thoracic Surgery, University of Health Sciences, İzmir Dr Suat Seren Chest Diseases and Surgery Medical Practice and Research Center, İzmir, Turkey

${ }^{2}$ Department of Pathology, University of Health Sciences, İzmir Dr Suat Seren Chest Diseases and Surgery Medical Practice and Research Center, İzmir, Turkey
'SBÜ İzmir Dr. Suat Seren Göğüs Hasalıkları ve Cerrahisi SUAM, Göğüs Cerrahisi Kliniği Kliniği, İzmir

${ }^{2} \mathrm{SBÜ̈}$ İzmir Dr. Suat Seren Gögüs Hasalıkları ve Cerrahisi SUAM, Patoloji Bölümü, İzmir

Submitted (Başvuru tarihi): 24.12.2019 Accepted (Kabul tarihi): 24.02.2020

Correspondence (iletişim): Ezgi Çimen Çelik, Department of Thoracic Surgery, University of Health Sciences, İzmir Dr Suat Seren Chest Diseases and Surgery Medical Practice and Research Center, İzmir, Turkey

e-mail: ezgi.guvenc@yahoo.com 
Amyloidosis is characterized by an accumulation of congophilic amyloid fibrin deposits in the extracellular matrix or organs (1). The most common forms are systemic AL amyloidosis, systemic AA amyloidosis, systemic wild-type ATTR amyloidosis, systemic hereditary ATTR amyloidosis and localized AL amyloidosis (2). Nodular pulmonary amyloidosis is a usual subtype of localized AL amyloidosis (3) that may be associated with underlying inflammatory or malignant conditions. Patients are generally asymptomatic $(4,5)$. Lesions are usually solitary, and may be mistaken for pulmonary malignancies. Biopsy material is stained with Congo-Red to give a green color under a polarized microscope, which is diagnostic (6). Excision of the nodules is usually curative and the prognosis is excellent (7). The case we present here is intended to emphasize that pulmonary amyloidosis is rare and may be mistaken for malignancies.

\section{CASE}

A 76-year-old female patient who underwent a right mastectomy 10 years previously for breast apocrine carcinoma followed by chemotherapy and radiotherapy, was diagnosed with pulmonary nodules in radiological followup and referred to us. No pathology was detected aside from the old operation scar on the right breast upon physical examination. Increased opacity was noted in the left paracardiac area on chest radiography. A thorax computed tomography (CT) showed a $13 \times 15 \mathrm{~mm}$ solid nodule in the left upper lobe (Figure 1 and 2), a $15 \times 20$ $\mathrm{mm}$ nodule in the lingual (Figure 3 and 4), and an $6 \times 8$ $\mathrm{mm}$ nodule in the left lower lobe (Picture 5). A positron emission tomography/computed tomography (PET-CT) revealed a $1.5 \times 1 \mathrm{~cm}$ nodule (SUVmax: 1.6) in the left upper lobe and a nodule of $2.2 \times 1.4 \mathrm{~cm}$ (SUVmax: 1.4) in the lingula (Figures 6, 7 and 8). Since the patient could not be diagnosed through bronchoscopy and transthoracic, a fine needle aspiration biopsy (TTFNAB), operation was selected for diagnosis and treatment. In an exploration with a left thoracotomy, four nodules in the left upper lobe and one nodule in the lower lobe were palpated. A wedge resection was performed on the three peripheral nodules in the left upper lobe and in the lower lobe, and the frozen section was examined. The frozen result report read "The nodules may be breast carcinoma metastasis, but a definitive diagnosis should be confirmed with further investigations." A left upper lobectomy was performed, since the other central lesion in the upper lobe could not be completely removed due to its closeness to the superior pulmonary vein. The final pathology was reported as nodular pulmonary amyloidosis (Figures 9, 10 and 11). The patient was discharged on the 7th postoperative day and is now in the 4th postoperative month.

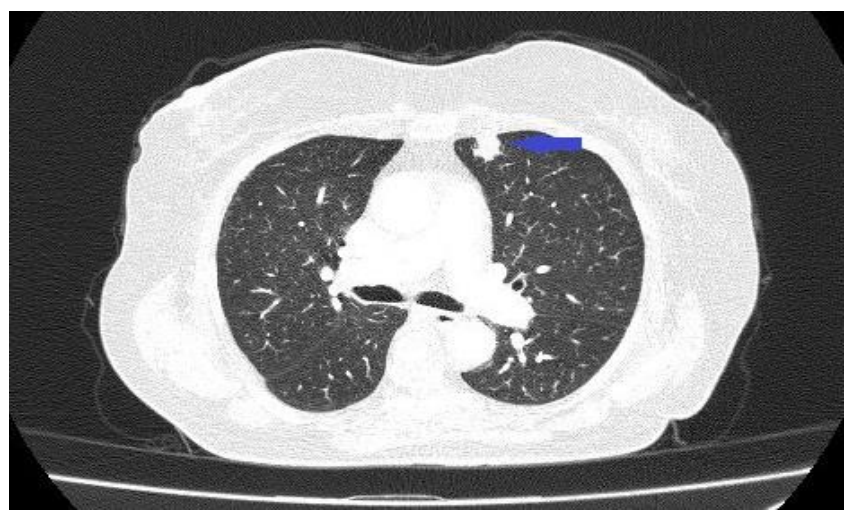

Figure 1: Thorax computed tomography showing a $13 \times 15 \mathrm{~mm}$ solid nodule in left lung upper lobe

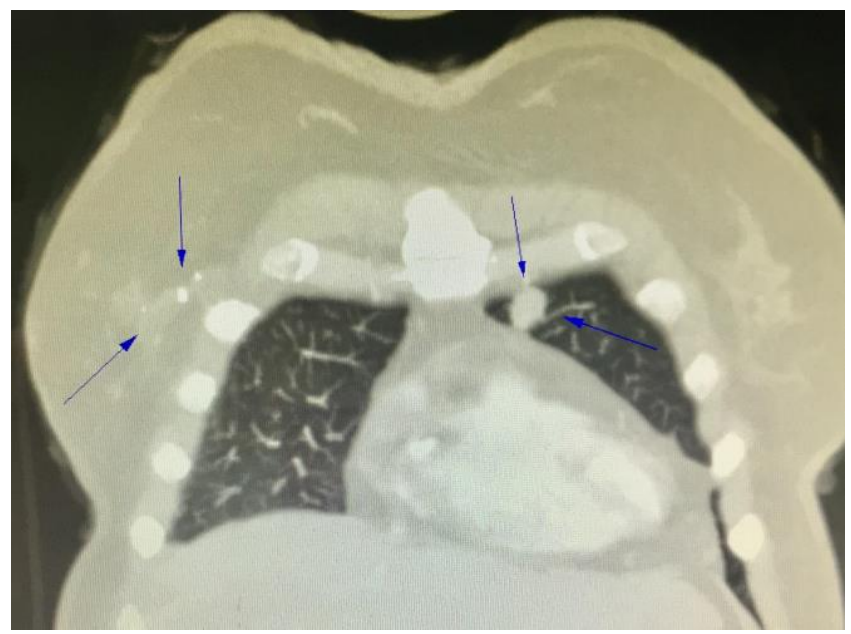

Figure 2: Thorax computed tomography showing a $13 \times 15 \mathrm{~mm}$ solid nodule in left lung upper lobe (Coronal section)

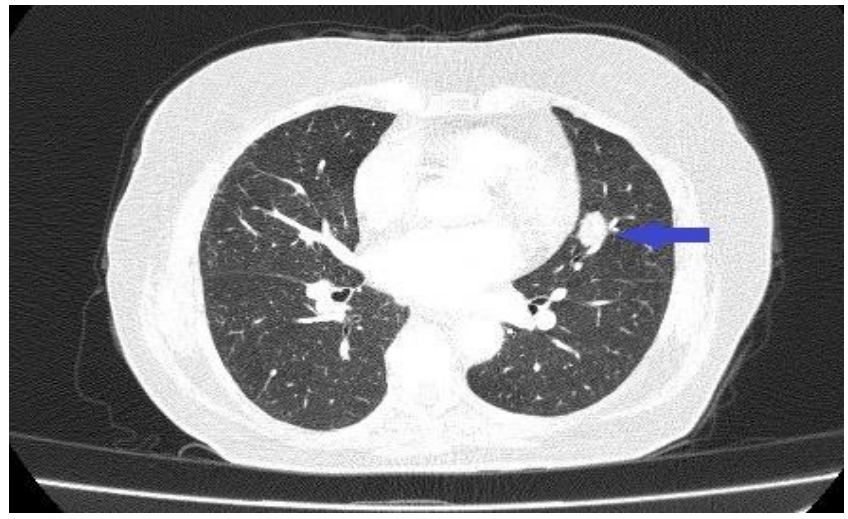

Figure 3: Thorax computed tomography showing a $15 \times 20 \mathrm{~mm}$ nodule in left lung lingual lobe 


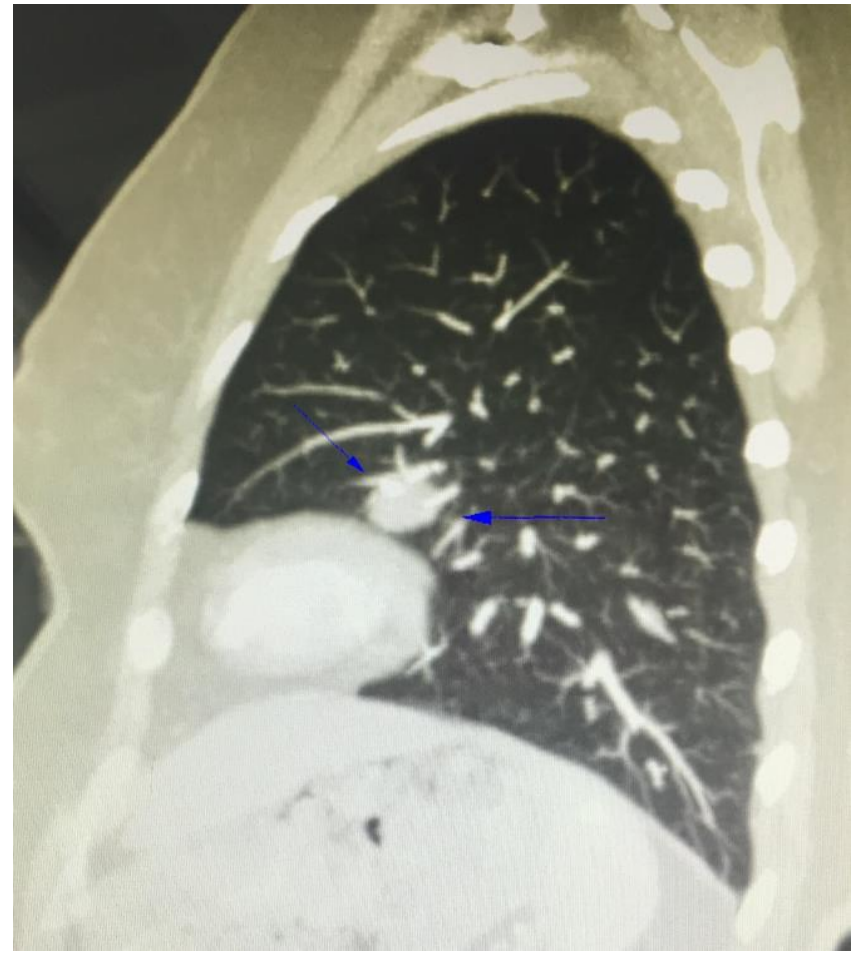

Figure 4: Thorax computed tomography showing a $15 \times 20 \mathrm{~mm}$ nodule in left lung lingual lobe (sagittal section)

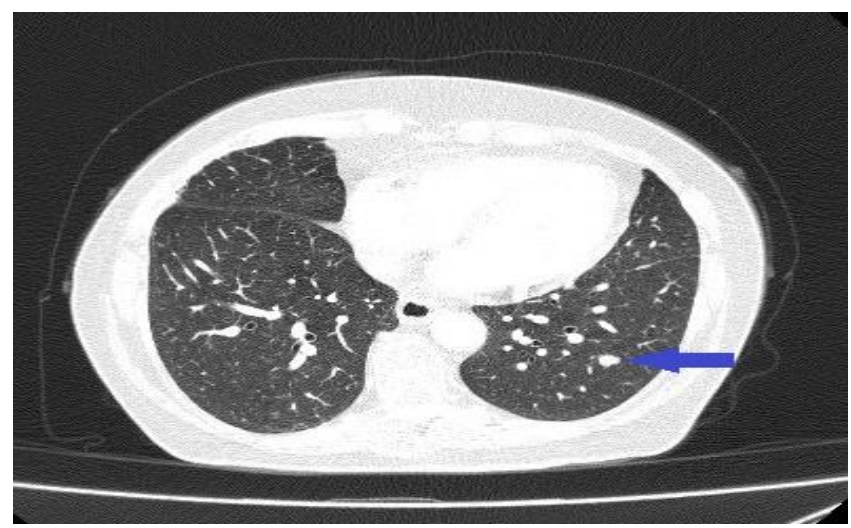

Figure 5: Thorax computed tomography showing a $6 \times 8 \mathrm{~mm}$ nodule in left lung lower lobe

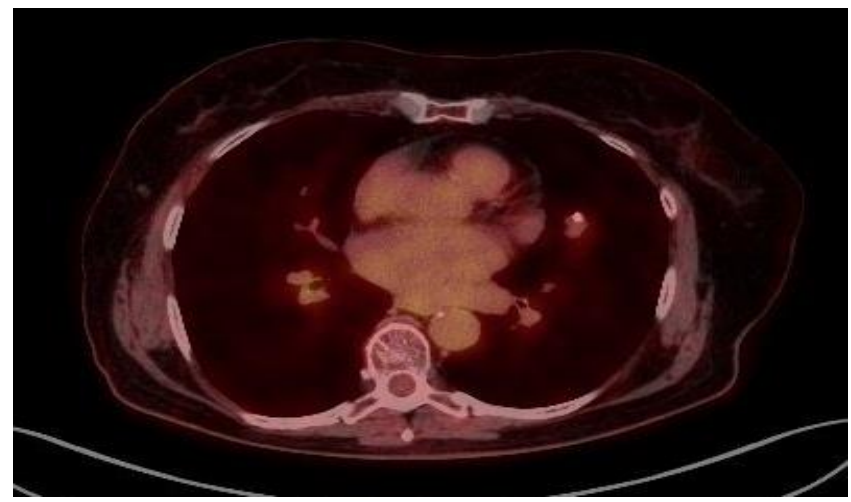

Figure 6: PET /CT showing a $1.5 \times 1 \mathrm{~cm}$ nodule (SUVmax: 1.6) in left lung upper lobe

\section{DISCUSSION}

Nodular pulmonary amyloidosis, known also as nodular parenchymal amyloidosis or nodular amyloidoma, is a disease that is characterized by the presence of one or more tumor-like amyloid deposits in the lung (1). It was first described by Virchow in 1857 (7). It is rarely seen among the amyloid diseases $(3,6)$, and is characterized primarily by a congophilic light chain amyloid (AL) deposition in the extracellular matrix, and may be solitary or, as with tour patient, multiple $(1,8)$. It is usually diagnosed in the sixth decade and is more common in men $(1,9)$. Patients are generally asymptomatic, as in our patient $(4,5)$, although it may cause cough, hemoptysis, dyspnea, pleural effusion and pulmonary arterial hypertension, depending on the location (10). It has no specific radiological findings and mimics malignancies radiologically. The present case emphasizes that pulmonary amyloidosis is rare and may be mistaken for malignancies. Our patient was operated on due to the suspicion of breast carcinoma metastasis.

18-Fluoro-deoxyglucose (18F-FDG) PET-CT has emerged as a tool for the diagnosis of pulmonary nodules to reduce invasive diagnostic examination. However, 18FFDG shows a small amount of uptake in malignancies with low metabolic activity, such as bronchoalveolar cancer, carcinoid tumor and mucinous adenocarcinoma. As such, despite low involvement on PET-CT (SUVmax: 1,6), malignancies can be considered in a pre-diagnosis. Furthermore, it has high metabolic rates alongside such nonmalignant conditions as tuberculosis, sarcoidosis and rheumatoid nodules. In our case, and as in other rarely reported cases, pulmonary nodular amyloidosis with low or moderate 18F-FDG involvement can be seen (11). As such, the results of an 18F-FDG PET-CT should be interpreted with caution in the differentiation of pulmonary amyloidosis from other malignant or benign lesions. A definitive diagnosis of localized pulmonary amyloidosis requires histological confirmation (12). In cases in which patient cannot be diagnosed via a CT-guided fine needle aspiration biopsy, an invasive surgical resection may be necessary. The patient in the present study could not be diagnosed via TFNAB, and so exploratory thoracotomy was decided upon. Furthermore, in the frozen examination, no differential diagnosis from malignancies could be made. 


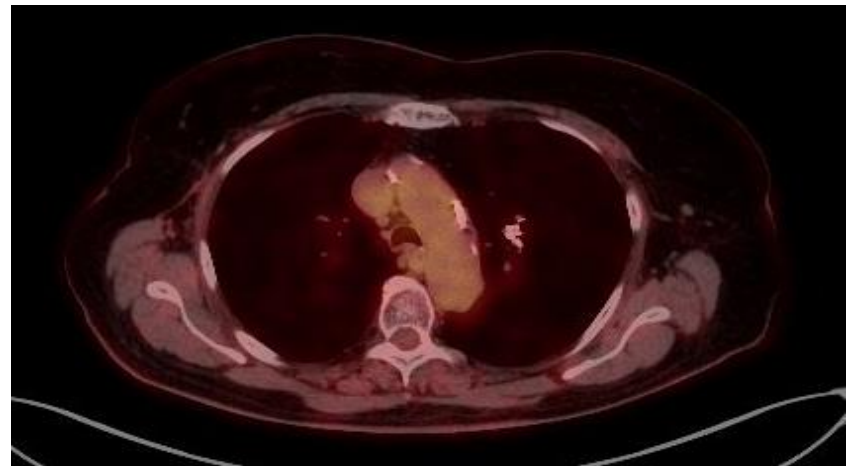

Figure 7: PET /CT showing a calcific nodul in left lung upper lobe

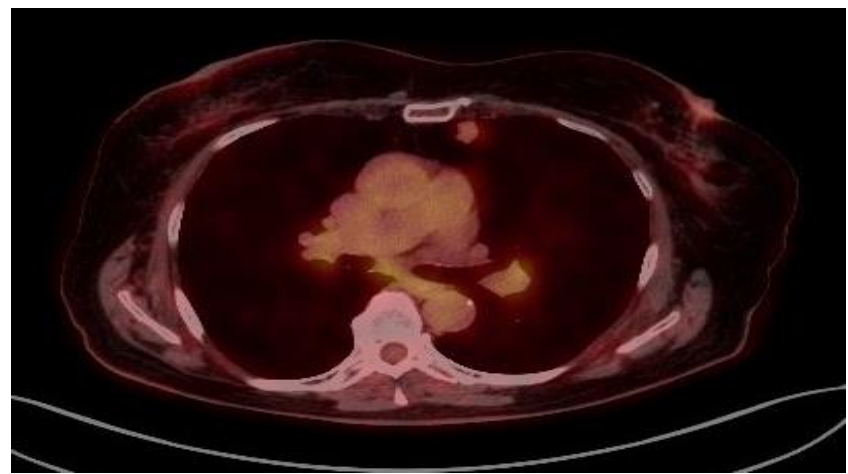

Figure 8: PET /CT showing a $2.2 \times 1.4 \mathrm{~cm}$ nodule (SUVmax: 1.4) in left lung lingula lobe

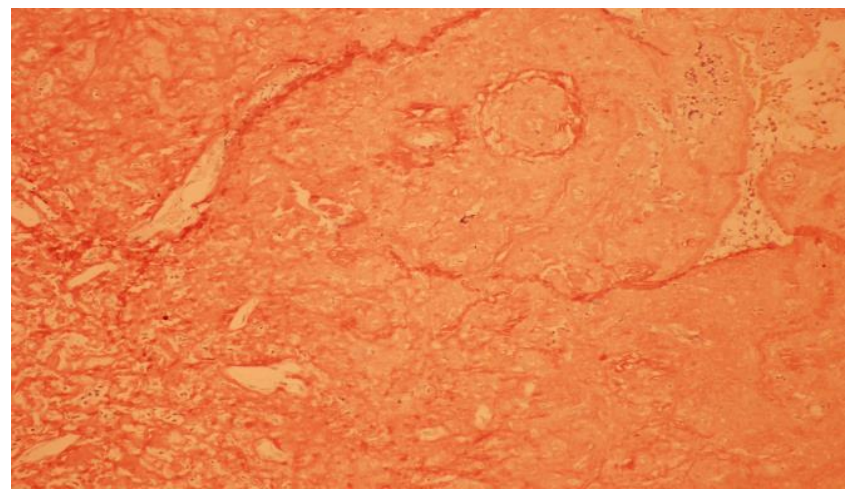

Figure 9: Congo red X 200

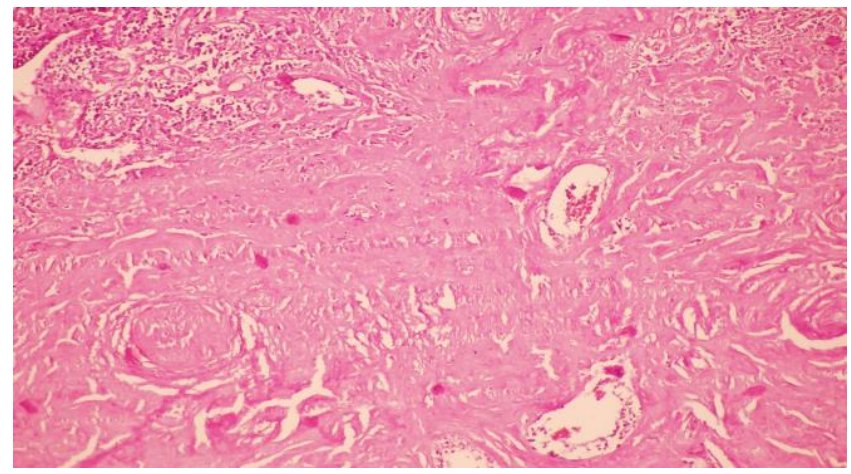

Figure 10: Acellular hyalinized material (H\&E X200)

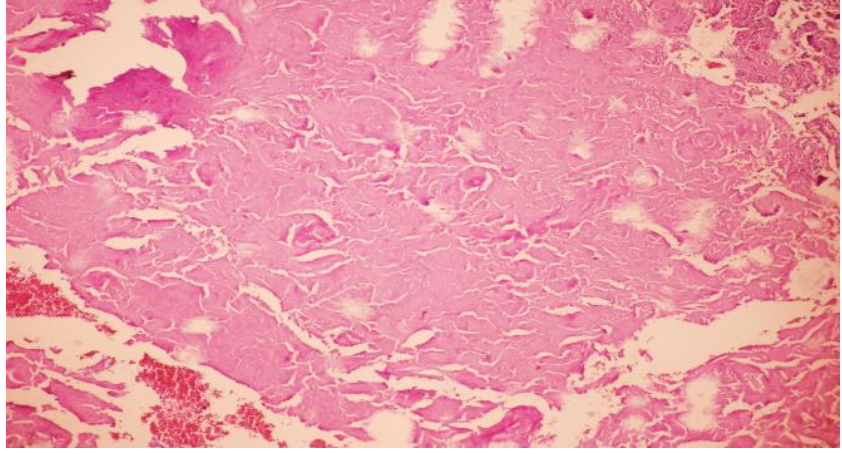

Figure 11: Acellular eosinophilic material (H\&E X200)

Pulmonary amyloidosis may occur as a component of localized or systemic amyloidosis $(12,13)$. Localized AL amyloidosis has a better prognosis than systemic amyloidosis. The 10-year survival rate after surgery is reported to be $97 \%$. A surgical resection can be performed safely, and the prognosis is excellent (13). Our patient continues to be followed-up without problem in the postoperative 4th month.

In conclusion, local nodular pulmonary amyloidosis is a rare and unusual tumor of the lung, and surgical treatment is curative. Nodules may be solitary or multiple. It should be kept in mind that amyloidosis may mimic both benign and malignant pathologies, and should be considered in a differential diagnosis.

\section{CONFLICTS OF INTEREST}

None declared.

\section{AUTHOR CONTRIBUTIONS}

Concept - E.Ç.Ç., S.Y., S.G., A.U., Z.A.; Planning and Design - E.Ç.Ç., S.Y., S.G., A.U., Z.A.; Supervision E.Ç.Ç., S.Y., S.G., A.U., Z.A.; Funding - E.Ç.Ç., Z.A.; Materials - S.Y., E.Ç.Ç., Z.A.; Data Collection and/or Processing - E.Ç.Ç., Z.A.; Analysis and/or Interpretation S.Y., S.G., E.Ç.Ç.; Literature Review - E.Ç.Ç.; Writing E.Ç.Ç.; Critical Review - S.Y., A.U., S.G.

\section{YAZAR KATKILARI}

Fikir - E.Ç.Ç., S.Y., S.G., A.U., Z.A.; Tasarım ve Dizayn E.Ç.Ç., S.Y., S.G., A.U., Z.A.; Denetleme - E.Ç.Ç., S.Y., S.G., A.U., Z.A.; Kaynaklar - E.Ç.Ç., Z.A.; Malzemeler S.Y., E.Ç.Ç., Z.A.; Veri Toplama ve/veya İşleme - E.Ç.Ç., Z.A.; Analiz ve/veya Yorum - S.Y., S.G., E.Ç.Ç.; Literatür Taraması - E.Ç.Ç.; Yazıyı Yazan - E.Ç.Ç.; Eleştirel İnceleme - S.Y., A.U., S.G. 


\section{REFERENCES}

1. Khoor A, Colby TV. Amyloidosis of the Lung. Arch Pathol Lab Med 2017; 141:247-54. [CrossRef]

2. Sipe JD, Benson MD, Buxbaum JN, Ikeda S, Merlini G, Saraiva MJ, et al. Nomenclature 2014: amyloidfibril proteins and clinical classification of the amyloidosis. Amyloid 2014; $21: 221-4$. [CrossRef]

3. Kaplan B, Martin BM, Boykov O, Gal R, Pras M, Shechtman I, et al. Co-deposition of amyloidogenic immunoglobulin light and heavy chains in localized pulmonary amyloidosis. Virchows Arch 2005; 447:756-61. [CrossRef]

4. Beer TW, Edwards CW. Pulmonary nodules due to reactive systemic amyloidosis (AA) in Crohn's disease. Thorax 1993; 48:1287-8. [CrossRef]

5. Roden AC, Aubry MC, Zhang K, Brady JO, Levin D, Dogan $A$, et al. Nodular senile pulmonary amyloidosis: a unique case confirmed by immunohistochemistry, mass spectrometry, and genetic study. Human Pathology 2010; 41:1040-5. [CrossRef]

6. Howie AJ, Brewer DB. Optical properties of amyloid stained by Congo red: history and mechanisms. Micron 2009; 40:285-301. [CrossRef]
7. Utz JP, Swensen SJ, Gertz MA. Pulmonary amyloidosis The Mayo Clinic experience from 1980 to 1993. Ann Intern Med 1996; 124;4, 407-13. [CrossRef]

8. Milani P, Basset M, Russo F, Foli A, Palladini G, Merlini G. The lung in amyloidosis. Eur Respir Rev 2017; 26(145): pii: 170046. [CrossRef]

9. Yang MC, Blutreich A, Das K. Nodular pulmonary amyloidosis with an unusual protein composition diagnosed by fine-needle aspiration biopsy: a case report. Diagn Cytopathol 2009; 37:286-9. [CrossRef]

10. Scala R, Maccari U, Madioni C, Venezia D, La Magra LC. Amyloidosis involving the respiratory system: 5-year's experience of a multi-disciplinary group's activity. Ann Thorac Med 2015, 10:212-6. [CrossRef]

11. Standaert C, Herpels V, Seynaeve P. A solitary pulmonary nodule: pulmonary amyloidosis. J Belg Soc Radiol 2018; 102:20. [CrossRef]

12. Chen KT. Amyloidosis presenting in the respiratory tract. Pathol Annu 1989; 24:253-273.

13. Baumgart JV, Stuhlmann-Laeisz C, Hegenbart U, Nattenmüller J, Schönland S, Krüger S, et al. Local vs. systemic pulmonary amyloidosis-impact on diagnostics and clinical management. Virchows Arch 2018; 473:627-37. [CrossRef] 